\title{
SUBSTANTIATION FOR THE TECHNOLOGY OF OBTAINING ANTIMICROBIAL SPRAY ON THE BASIS OF SILVER AND COPPER CITRATES
}

\author{
Zhanna Polova \\ Department of pharmaceutical and industrial technology of medicines \\ O. O. Bogomolets National Medical University \\ 13 T. Shevchenko blvd., Kyiv, Ukraine, 01601 \\ zpolova@ukr.net \\ Lyudmyla Almakayeva \\ Laboratory of parenteral and oral liquid medicines \\ National University of Pharmacy \\ 53 Pushkinska str., Kharkiv, Ukraine, 61002 \\ almakaeva@ukr.net
}

\begin{abstract}
Formation and development of the veterinary pharmacy and veterinary drugs market in Ukraine is an urgent issue. In order to prevent infection of the mammary gland in cows after milking, the nipples are treated with a suitable disinfectant for complete immersion or spraying. However, the agents for the prevention of mastitis, presented in the Ukrainian market, are expensive and there is a need to develop domestic veterinary preparations of different forms of release.

This work is a continuation of research on the development of the composition and technology of a means for antiseptic treatment of nipples and udders of cattle, in the form of a spray, in order to prevent microbial contamination and prevent mastitis.

To obtain a stable veterinary drug based on citrate of silver and copper, the dissolution regimes of the substances were investigated, the order of introduction of the active ingredients and auxiliary substances into the solution, the duration and the rate of stirring during dissolution. It is established that the most optimal are the following technological modes of spray preparation: dissolution temperature $20-22{ }^{\circ} \mathrm{C}$, mixing time from 10 to 15 minutes, with stirring intensity from $150-200 \mathrm{sec}^{-1}$. The selected technological regime ensures the stability of the veterinary drug "Argocide-copper" during storage for 12 months. The technology of obtaining a spray in the conditions of industrial production of veterinary preparations of LLC "Brovafarm" (Brovary, Ukraine) is developed. Critical stages and critical control points in the production process of a veterinary preparation of antiseptic action are determined.
\end{abstract}

Keywords: silver citrate, copper citrate, spray, antiseptic action, prevention of mastitis.

\section{Introduction}

An important task of modern pharmaceutical technology is the creation of effective and safe medicines, including veterinary pharmacy. Formation and development of the veterinary pharmacy and veterinary drugs market in Ukraine is an urgent issue, which is connected with modern processes in society [1]. The problem of mastitis in productive animals is urgent. The content of cattle on a limited area of farms leads to an increase in microbial contamination and an increase in the virulent properties of the opportunistic bacterial flora. High milk production causes the intense functioning of the mammary gland, accompanied by a decrease in organ resistance, resulting in inflammation [2]. Therefore, growth the importance of veterinary and sanitary measures, especially the prevention and treatment of breast diseases of cattle [3]. At the current stage of livestock development, there is no one agro-industrial economy of Ukraine that would have bypassed the problem of mastitis cattle. Mastitis causes considerable economic damage for all countries of the world. The main costs include a decrease in the dairy productivity of animals [4].

In the treatment of mastitis in cows, antibiotic solutions for parenteral administration and suspension in syringe tubes for intracisternal use are most often used [5]. Modern anti-mastics are also produced by pharmaceutical factories in the form of gels, ointments, emulsions, suspensions and solutions for external use, etc. [6]. According to the State Veterinary 
and Phytosanitary Service of Ukraine, as of 2017, 46 trade names for cattle mastitis products were registered on the veterinary drugs market of the country [7]. But, experience shows that the problem of improving dairy herds from mastitis is not always solved by medical measures, they must be supported by a set of organizational, economic, zootechnical, veterinary and sanitary measures aimed at increasing the nonspecific resistance of the organism, timely elimination of causes and factors contributing to the emergence of new cases disease [8].

In order to prevent infection of the mammary gland in cows after milking, the nipples are treated with a suitable disinfectant for complete immersion or spraying. For antiseptic treatment of the udder are used agents containing various antiseptic or disinfecting compounds, such as chlorhexidine, hydrogen peroxide, bleach, quinazole, phenol and its derivatives $[9,10]$. Iodine compounds have become very popular in the prophylactic preparations for the treatment of cattle's udder $[11,12]$. Disadvantages of such drugs may be low effectiveness of treatment, and the possibility of causing side effects.

It is established that the drugs for the prevention of mastitis, presented in the Ukrainian market, are costly and there is a need to develop domestic veterinary preparations of different forms of release [13].

This work is a continuation of the research on the development of the composition and technology of a means for antiseptic treatment of the nipples and udder of cattle in the form of a spray under the conventional name "Argocide-copper", with the aim of preventing microbial contamination and preventing mastitis $[14,15]$.

\section{Aim of the research}

Substantiation of the technology of obtaining an antimicrobial spray based on silver and copper citrate in industrial conditions, determination of critical stages and critical control points in the production process.

\section{Materials and methods}

As a research object were chosen a series of preparations with the following proportions of the components of mass \%: silver citrate 15.0-30.0; copper citrate 15.0-30.0; dexpanthenol 0.5-5; polyquaternium $100.1-1.0$; polysorbate 20 0.2-3.0; essential oil of lemon $0,01-2,0$; essential oil of juniper 0.01-2.0; water purified to 100.0. The active substances - silver and copper citrate, manufactured by Nanomaterials and Nanotechnologies Ltd., Kyiv, Ukraine, D - panthenol USP (BASF SE, Germany) were used.

The quantitative content of silver ions in the spray was determined by thiocyanometry [16]. The quantitative content of copper ions was determined according to the method of the State Pharmacopoeia of Ukraine 2.0 (SPhU) "2.2.25 Absorption spectrophotometry in the ultraviolet and visible regions". Quantitative determination of dexpanthenol was carried out by liquid chromatography according to the procedure of $\mathrm{SPhU}$ "2.2.29. Liquid chromatography. Potentiometric determination of the $\mathrm{pH}$ of the experimental samples was carried out according to the procedure of $\mathrm{SPhU}$ 2.0, item 2.2.3. The measurements were carried out using a $\mathrm{pH}$ meter "Seven Easy $\mathrm{pH}$ " complete with electrodes manufactured by Mettler Toledo (China). The dissolution criterion was the absence of "visible particles" in the solution. Statistical processing of experimental data was carried out in accordance with the requirements of the article SPhU 2.0 "5.3.N.1. Statistical analysis of the results of a chemical experiment" [17].

\section{Results}

To obtain a stable veterinary drug in the form of a silver citrate and copper spray for veterinary medicine, the dissolution regimes of the substances, the order of administration of the active ingredients and auxiliary substances into the solution, the duration and rate of stirring during dissolution were investigated [18]. The order of administration of ingredients is one of the most important factors for obtaining a stable dosage form for veterinary medicine.

The calculated volume of the silver citrate and copper citrate solution was loaded into the reactor and purified water was added from the collection tank at a temperature of $(20 \pm 5){ }^{\circ} \mathrm{C}$, then 
the reactor was loaded sequentially with stirring: dexpanthenol, stirred for 10-15 minutes; polyquaternium - 10, mixed for 15-20 minutes. Lemon and juniper oil were mixed in a separate container with a calculated amount of polysorbate 20, and then added to the stock solution, mixing until completely dissolved.

At the same time, technological parameters were processed, including the temperature and time regimes, the duration and speed of mixing during the preparation of the solution. Since the stability of the solution of citrate of silver and copper depends on the temperature, and the solution of silver citrate is not recommended to be heated to a temperature above $500{ }^{\circ} \mathrm{C}$, so the preparation of the solution should be carried out at a temperature of $20-22{ }^{\circ} \mathrm{C}$.

We studied the dissolution rate of the components at the chosen temperature regime. Intensity - the speed of achieving the required technological result - the time spent on the distribution of the disperse phase in the volume of the continuous phase with the required degree of uniformity. The results of the studies are presented in Table. 1.

Table 1

The dissolution rate of the components at the chosen temperature regime

\begin{tabular}{|c|c|c|c|}
\hline $\begin{array}{c}\text { Serial } \\
\text { number }\end{array}$ & Temperature, ${ }^{\circ} \mathrm{C}$ & $\begin{array}{l}\text { Number of revolutions of } \\
\text { stirrer, } \sec ^{-1}\end{array}$ & $\begin{array}{l}\text { Duration of stirring to } \\
\text { the absence of insoluble particles in } \\
\text { solution, min. }\end{array}$ \\
\hline 1 & $20-22$ & 50 & $20-30$ \\
\hline 2 & $20-22$ & 100 & $15-20$ \\
\hline 3 & $20-22$ & 150 & $10-15$ \\
\hline 4 & $20-22$ & 200 & $10-15$ \\
\hline
\end{tabular}

When developing the technology of spray preparation, several preparation regimes were studied to obtain a solution that is free from undissolved particles-with different durations and mixing speeds. It was found that with a shorter mixing speed, a longer mixing time is required, and on the basis of the results obtained, an optimum dissolution time of 10-15 min was chosen which was fixed at a stirring speed of 150-200 $\mathrm{sec}^{-1}$.

We also studied the quality indicators of the veterinary drug "Argocide-copper" after 12 months of storage. The results are shown in Table. 2 .

As follows from Table 1, 2, the following technological modes of preparation of an antiseptic spray are considered to be the most optimal: dissolution temperature $20-22{ }^{\circ} \mathrm{C}$, mixing time from 10-15 minutes, with stirring intensity from $150-200 \mathrm{sec}^{-1}$.

Table 2 shows the quality of the spray after 12 months. storage, which indicates that the spray produced by observing the selected optimal values of the dissolution process (temperature 20-220 ${ }^{\circ} \mathrm{C}$, duration $10-15 \mathrm{~min}$, stirring speed $150-200, \mathrm{sec}^{-1}$ ), retains the values of these indicators within the limits specified in the draft analytical documentation.

It can be argued that the selected technological mode of preparation of the spray based on citrate of silver and copper ensures the stability of the veterinary drug "Argocide-copper" during storage for 12 months.

The next stage of the research was the development of a technological process for obtaining a veterinary drug for external use. Preparation of a solution of an antimicrobial medicine based on active silver and copper ions was carried out in a reactor equipped with an anchor stirrer. Equipment in which the solution can be exposed to light must be covered. 50 litres of silver citrate and copper citrate solution were charged to the reactor and 20 litres of 
purified water at a temperature of $(20 \pm 5) \mathrm{C}$ were added from the collector, then, sequentially: dexpanthenol was added to the reactor with stirring, and stirred for 10-15 minutes; polyquaternium - 10, mixed for 15-20 minutes.

Table 2

Quality indicators of the spray "Argocide-copper" after 12 months of storage.

\begin{tabular}{|c|c|c|c|c|c|c|}
\hline \multirow{3}{*}{$\begin{array}{c}\text { Serial } \\
\text { number }\end{array}$} & \multicolumn{6}{|c|}{ Quality indicators according to regulatory documentation } \\
\hline & Descrintion & & & & lantitative content, $\%$ & \\
\hline & $\begin{array}{c}\text { a greenish-blue } \\
\text { color) }\end{array}$ & $\begin{array}{l}\text { (from } 1.016 \\
\text { to } 1.018)\end{array}$ & $(2.0-5.0)$ & $\begin{array}{c}\text { Ions of silver } \\
\text { (not less than 0.0113) }\end{array}$ & $\begin{array}{l}\text { Copper ions (not less } \\
\text { than } 0.0113 \text { ) }\end{array}$ & $\begin{array}{c}\text { Dexpanthenol } \\
(4.75-5.25)\end{array}$ \\
\hline 1 & + & 1.016 & $2.15 \pm 0.01$ & $0.0126 \pm 0.0002$ & $0.0126 \pm 0.0002$ & $5.10 \pm 0.01$ \\
\hline 2 & + & 1.017 & $2.13 \pm 0.03$ & $0.0125 \pm 0.0001$ & $0.0127 \pm 0.0001$ & $5.09 \pm 0.02$ \\
\hline 3 & + & 1.016 & $2.14 \pm 0.03$ & $0.0125 \pm 0.0002$ & $0.0125 \pm 0.0002$ & $5.09 \pm 0.01$ \\
\hline 4 & + & 1.016 & $2.15 \pm 0.03$ & $0.0125 \pm 0.0001$ & $0.0125 \pm 0.0001$ & $5.08 \pm 0.03$ \\
\hline
\end{tabular}

Note: + - matches; $P \pm 95 \%, n=5$

Polysorbate 20 was placed in a separate vessel with a stirrer and a stirrer was turned on. With the stirrer on, lemon oil and juniper oil were added. Mixing was conducted until a homogeneous solution was obtained, at least 15 minutes. Then the contents of the collector, quantitatively transferred to a reactor with a solution of silver citrate, copper citrate, dexpanthenol and polyquaternium 10, were mixed until a homogeneous solution was obtained for at least 15 minutes. Then the solution volume in the reactor was adjusted to $100.0 \mathrm{~L}$ with water and stirred for 10-15 minutes. At the end of the preparation process, an average sample was taken to control the intermediate product according to the developed analytical normative document for the following parameters: $\mathrm{pH}$ of the solution; the quantitative content of silver and copper ions, dexpanthenol; appearance. The results are shown in Table 3.

After monitoring the intermediate product and obtaining positive results, the solution under pressure of inert gas (nitrogen) is transferred to the filters for filtration of the solution with charging by the "FILTRAK" filter paper of medium microporosity. It is necessary to control the brand of the filter, its integrity, the filtration regime (pressure $0.08-0.10 \mathrm{MPa}$ ). The solution after the filter enters the collection of the filtered solution. The filtered solution is monitored in terms of: description (hazy liquid of a greenish-blue color), coarse mechanical inclusions (absence), relative density $\left(1.016-1.018 \mathrm{~g} / \mathrm{cm}^{3}\right)$. The results are shown in Table 4.

When the positive results of the intermediate control were received, the filtered solution entered the filling of the vials and their capping. The preparation of the primary packaging was carried out in accordance with the company's document regulating the preparation of primary packaging materials.

Filling the vials with a solution and capping the caps of the spray was carried out on an automatic line for filling and capping the vials. After filling, the vials with the solution of the drug are moved to the capping zone, where the cap of the spray is screwed onto the neck. The intermediate product (bottles with solution) was monitored in terms of: the volume of the contents of the package $(200 \mathrm{ml})$, the quality of the closure (no leakage of the solution, no deformation 
of the vial and the spray cap). The sealed bottles are monitored on tables for viewing with the naked eye in a darkened room on a black and white background illuminated by a $100 \mathrm{~W}$ electric lamp. Indicators for control: the presence of visible mechanical inclusions, the volume of filling (visually), the quality of capping. Vials with mechanical inclusions, incomplete dosage, as well as with vial defects and capping are discarded. The vials, which passed control, are given for labeling and packaging.

Table 3

The study of the quality indicators of the intermediate product in the preparation of the spray "Argocidecopper"

\begin{tabular}{|c|c|c|c|c|c|}
\hline \multirow[b]{2}{*}{$\begin{array}{c}\text { Serial } \\
\text { number }\end{array}$} & \multicolumn{5}{|c|}{ Quality indicators according to regulatory documentation } \\
\hline & $\begin{array}{c}\text { Appearance } \\
\text { (unclear liquid of } \\
\text { a greenish-blue } \\
\text { color) }\end{array}$ & $\begin{array}{c}\text { pH of } \\
\text { the solution } \\
(2.0-5.0)\end{array}$ & $\begin{array}{l}\text { The quantitative con- } \\
\text { tent, \% silver ions } \\
\text { (not less than } 0.0113 \text { ) }\end{array}$ & $\begin{array}{c}\text { The quantitative } \\
\text { content, \% copper ions } \\
\text { (not less than } 0.0113 \text { ) }\end{array}$ & $\begin{array}{c}\text { The quantitative con- } \\
\text { tent, \% dexpanthenol } \\
(4.75-5.25)\end{array}$ \\
\hline 1 & matches & $2.17 \pm 0.01$ & $0.0127 \pm 0.0002$ & $0.0126 \pm 0.0002$ & $5.03 \pm 0.03$ \\
\hline 2 & matches & $2.15 \pm 0.02$ & $0.0126 \pm 0.0003$ & $0.0127 \pm 0.0001$ & $5.01 \pm 0.03$ \\
\hline 3 & matches & $2.14 \pm 0.03$ & $0.0126 \pm 0.0003$ & $0.0125 \pm 0.0003$ & $5.01 \pm 0.03$ \\
\hline
\end{tabular}

Note: $P \pm 95 \%, n=5$

Table 4

The study of the quality of the intermediate product (filtered solution) in the preparation of the spray "Argocide-copper"

\begin{tabular}{|c|c|c|c|c|c|c|}
\hline \multirow{3}{*}{$\begin{array}{c}\text { Serial } \\
\text { number }\end{array}$} & \multicolumn{6}{|c|}{ Quality indicators according to regulatory documentation } \\
\hline & \multirow{2}{*}{$\begin{array}{l}\text { Description } \\
\text { (unclear liquid } \\
\text { of a greenish- } \\
\text { blue color) }\end{array}$} & \multirow{2}{*}{$\begin{array}{c}\text { Relative } \\
\text { density, } \\
\text { g/cm } \\
\text { (from } 1.016 \\
\text { to } 1.018 \text { ) }\end{array}$} & \multirow[b]{2}{*}{ pH (2.0-5.0) } & \multicolumn{3}{|c|}{ Quantitative content, \% } \\
\hline & & & & $\begin{array}{l}\text { Ions of silver (not } \\
\text { less than } 0.0113 \text { ) }\end{array}$ & $\begin{array}{l}\text { Copper ions (not } \\
\text { less than } 0.0113 \text { ) }\end{array}$ & $\begin{array}{c}\text { Dexpanthenol } \\
(4.75-5.25)\end{array}$ \\
\hline 1 & + & 1.017 & $2.15 \pm 0.03$ & $0.0127 \pm 0.0002$ & $0.0126 \pm 0.0002$ & $5.03 \pm 0.03$ \\
\hline 2 & + & 1.017 & $2.14 \pm 0.03$ & $0.0126 \pm 0.0003$ & $0.0127 \pm 0.0001$ & $5.02 \pm 0.02$ \\
\hline 3 & + & 1.016 & $2.14 \pm 0.03$ & $0.0127 \pm 0.0002$ & $0.0125 \pm 0.0003$ & $5.01 \pm 0.03$ \\
\hline
\end{tabular}

Note: + matches; $P \pm 95 \%, n=5$

Before being sent to the quarantine storage room, the TCD controller selects an average sample from the finished product series for a full analysis in accordance with normative analytical documentation. Before receiving the results of the analysis, the drug series is located in the quarantine storage room. The scheme of the technological process for the production of a veterinary drug is shown in Fig. 1. 
Raw materials, intermediate products, materials

Sanitary and technical preparation of production

Raw materials from the warehouse: a solution of citrates of silver and copper, dexpanthenol,

polyquaternium-10, polysorbate 20 , lemon and juniper oil

Water purified from the water treatment site

Bottles, spray caps, packaging materials

Solution of citrates of silver and copper, dexpanthenol, polyquaternium-10, polysorbate 20 , lemon oil, juniper oil, purified water from stage 2

The solution filtered from stage 3

Bottles, caps of spray from stage 2
Preparation of the solution

Control in the production process

Stage 1

Sanitary preparation of production

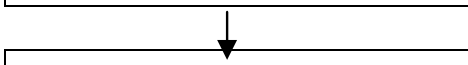

Stage 2

Preparation of raw

materials, auxiliary

materials and primary packaging

Scales KP-1, KP-2,

Machine for washing bottles Drying cabinet

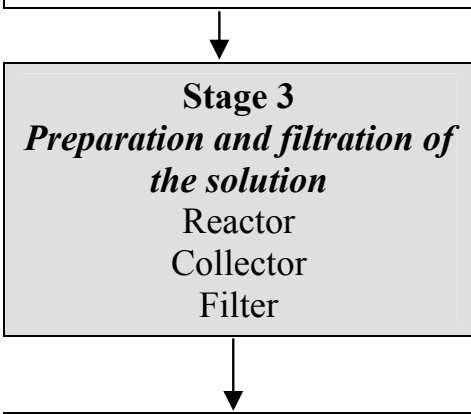

Stage 4

Filling the bottles with

solution and sealing

Filling and capping machine
Microbiological contamination of industrial premises, equipment

Input control of raw materials, primary packaging, packaging and printed materials Control of the mass of raw material weights. Control of the mode of preparation of the primary packaging.

Control of preparation mode,

Control of the intermediate product

Filling mode control, filling volume control, intermediate product control

\section{Marking, packaging and shipment of the}

finished product

Solution based on active silver and copper ions in vials from stage 4

Packaging and printing materials from stage 2

\section{Solution based on active silver and copper ions in vials from stage 4 Packaging and printing materials from stage 2}

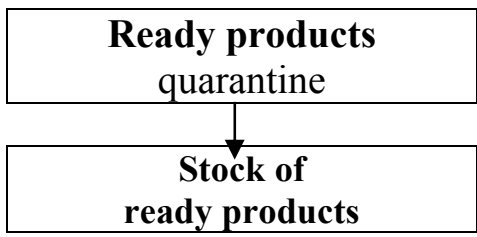

Control of the intermediate product Quality of labeling and labeling of bottles and packaging

Control of ready products

Fig. 1. Block diagram of the technological process of production of the drug "Argocide-copper" in the form of a spray: in gray are critical stages and critical control points in the production process 


\section{Discussion}

It should be noted that the production of veterinary drugs in Ukraine in accordance with the requirements of good practices is at the implementation stage. The EU Commission adopted directives establishing the principles and rules of GMP for medicines and veterinary drugs. Directive 2003/94/EC refers to medicines for humans, and Directive 91/412/EC - medicines for veterinary use $[19,20]$. The detailed requirements are in accordance with the principles of Directive 91/412/EEC set out in the "Guidelines for Basic Rules of Good Practice in the Production and Quality Control of Veterinary Preparations", based on which the manufacturers of veterinary drugs in Ukraine will be inspected [21].

Medicines for veterinary use are made using materials and methods that ensure microbiological purity, prevent contamination of medicines and the growth of microorganisms. We tested the technology of the drug "Argocide-copper" under the conditions of the industrial production of veterinary preparations of LLC Brovafarm (Brovary, Ukraine), which allowed to develop and standardize it in normative and technological documentation (NTD). NTD consists of the technological regulations (it includes product data and technological instructions), packing instructions and corresponding protocols.

Production of the drug in the form of a spray based on active ions of silver and copper was carried out taking into account sanitary and hygienic requirements aimed at preventing microbial contamination of raw materials and finished products. For this purpose, the sanitary preparation of the production was carried out, which includes the operations of preparation of disinfectant solutions, preparation of ventilation air, production facilities, equipment and inventory, special clothing and personnel for work.

The process of production of the drug "Argocide-copper" was carried out in premises with a class of purity $\mathrm{C}, \mathrm{D}$, which is determined by the content of the maximum permissible mechanical particles and microorganisms in the air of the working zone. In the premises of cleanliness class $\mathrm{C}$, the preparation, filtration, filling and sealing of the primary packaging, preparation of special clothes and personnel were carried out; in the purity class D, primary packaging (bottles, lids) was prepared, labeling and packaging of the vials into packs.

\section{Conclusions}

1. The effects of the preparation regimes and the order of administration of the components in the spray under the provisional name "Argocide-copper" on the stability of the preparation based on silver citrate and copper for veterinary medicine were studied.

2. It is found that the most optimal are the following technological modes of spray preparation: dissolution temperature $20-22{ }^{\circ} \mathrm{C}$, mixing time from $10-15$ minutes, with stirring intensity from 150-200 $\mathrm{sec}^{-1}$. The chosen technological mode11 of preparation of a spray based on citrate of silver and copper ensures the stability of the veterinary drug "Argocide-copper" during storage for 12 months.

3. The technology of obtaining a spray in the conditions of industrial production of veterinary preparations of LLC "Brovafarm” (Brovary, Ukraine) has also been developed. Critical stages and critical control points were determined during the production of a veterinary preparation of antiseptic action.

\section{Acknowledgement}

The work was carried as a part of research work: "Marketing, pharmacoeconomic and technological research on the development of medicines" (State registration number in Ukraine 0115U001530).

\section{References}

[1] Polova, Zh. M. (2014). Analiz rynku veterynarnykh likarskykh form dlia zastosuvannia v akusherstvi ta hinekolohii. Farmatsevtychnyi chasopys, 4 (32), 129-134. 
[2] De Vliegher, S., Fox, L. K., Piepers, S., McDougall, S., Barkema, H. W. (2012). Invited review: Mastitis in dairy heifers: Nature of the disease, potential impact, prevention, and control. Journal of Dairy Science, 95 (3), 1025-1040. doi: 10.3168/jds.2010-4074

[3] Ruegg, P. L. (2009). Management of mastitis on organic and conventional dairy farms1. Journal of Animal Science, 87, 43-55. doi: 10.2527/jas.2008-1217

[4] Sinha, M. K., Thombare, N. N., Mondal, B. (2014). Subclinical Mastitis in Dairy Animals: Incidence, Economics, and Predisposing Factors. The Scientific World Journal, 2014, 1-4. doi: $10.1155 / 2014 / 523984$

[5] Ranjan, R., Gupta, M. K., Singh, S., Kumar, S. (2010). Current trend of drug sensitivity in bovine mastitis. Veterinary World, 3 (1), 17-20.

[6] Yarnykh, T. H., Orlovetska, N. F., Khokhlenkova, N. V., Dukhnytskyi, V. B., Chushenko, V. M.; Yarnykh, T. H. (Ed.) (2010). Praktykum z tekhnolohii veterynarnykh preparativ. Kharkiv: $\mathrm{NFaU}, 179$.

[7] Nemchenko, A., Polova, Z., Nazarkina, V., Simonyan, L. (2017). Marketing researches of the veteri nary drugs market used in mastitis treatment of cattle. Management, Economics and Quality Assurance in Pharmacy, 2 (50), 93-97. doi: 10.24959/uekj.17.17

[8] Garvey, M., Curran, D., Savage, M. (2016). Efficacy testing of teat dip solutions used as disinfectants for the dairy industry: Antimicrobial properties. International Journal of Dairy Technology, 70 (2), 179-187. doi: 10.1111/1471-0307.12344

[9] Mason, S. E., Mullen, K. A. E., Anderson, K. L., Washburn, S. P., Yeatts, J. L., Baynes, R. E. (2017). Pharmacokinetic analysis of thymol, carvacrol and diallyl disulfide after intramammary and topical applications in healthy organic dairy cattle./ Food Additives \& Contaminants: Part A: Chemistry, Analysis, Control, Exposure \& Risk Assessment, 70 (2), 179-187. doi: 10.1080/19440049.2017.1285056

[10] DeLaval. Available at: https://www.delaval.com/en-us/

[11] Martins, C. M. M. R., Pinheiro, E. S. C., Gentilini, M., Benavides, M. L., Santos, M. V. (2017). Efficacy of a high free iodine barrier teat disinfectant for the prevention of naturally occurring new intramammary infections and clinical mastitis in dairy cows. Journal of Dairy Science, 100 (5), 3930-3939. doi: 10.3168/jds.2016-11193

[12] French, E. A., Mukai, M., Zurakowski, M., Rauch, B., Gioia, G., Hillebrandt, J. R. et. al. (2016). Iodide Residues in Milk Vary between Iodine-Based Teat Disinfectants. Journal of Food Science, 81 (7), 1864-1870. doi: 10.1111/1750-3841.13358

[13] Polova, Zh. M., Nazarkina, V. M. (2017). The analysis of economic availability of veterinary preparations in the segment of anti-mastitis medicines. Social Pharmacy in Health Care, 3 (3), 35-41. doi: $10.24959 /$ sphhcj.17.86

[14] Polova, Zh. M. (2016). Doslidzhennia antymikrobnoi aktyvnosti tsytrativ sribla ta midi z metoiu rozrobky farmatsevtychnykh preparativ. Aktualni pytannia farmatsevtychnoi i medychnoi nauky ta praktyky, 1 (20), 71-74

[15] Polova, Zh. M. (2016). Mikrobiolohichni doslidzhennia antyseptychnoho zasobu. Zbirnyk naukovykh prats spivrobitnykiv NMAPO imeni P.L.Shupyka, 25 (1), 563-568.

[16] Bezuglyi, P. O., Ukrayinecz, I. V., Taran, S. G. et. al.; Bezuglyi, P. O. (Ed.) (2002). Pharmaceutical chemistry. Kharkiv: National University of Pharmacy, 448. 
[17] State Pharmacopoeia of Ukraine. Vol. 1 (2015). Kharkiv: State Enterprise «Ukrainian Research Center expert pharmacopoeia drug quality», 1128.

[18] Liapunov, M. et. al. (2012). Likarski zasoby. Farmatsevtychna rozrobka (ICH Q8): Nastanova ST N MOZU 42-3.0:2011. Kyiv: MOZU Ukrainy, 35.

[19] Commission Directive 91/412/EEC of 23 July 1991 laying down the principles and guidelines of good manufacturing practice for veterinary medicinal products (1991). J. of the Eur. Com. L, 228, 70-73.

[20] Commission Directive 2009/9/EC of 10 February 2009 amending Directive 2001/82/EC of the European Parliament and of the Council on the Community code relating to medicinal products for veterinary use (2009). Official Journal, 44, 10-61.

[21] Metodychni rekomendatsii shchodo osnovnykh pravyl nalezhnoi praktyky vyrobnytstva ta kontroliu yakosti veterynarnykh preparativ [Methodological recommendations on the basic rules of good manufacturing practice and quality control of veterinary drugs] (2014). Available at: http://search. ligazakon.ua/1_doc2.nsf/link1/FN001635.html 